\title{
PENGGUNAAN MODEL PEMBELAJARAN PROBLEM BASED LEARNING UNTUK MENINGKATKAN HASIL BELAJAR SISWA MATERI ARITMETIKA SOSIAL
}

\author{
Elfrida Kolo ${ }^{*}$, Selestina Nahak ${ }^{2}$, Hermina Disnawati ${ }^{3}$ \\ ${ }^{1}$ Mahasiswa Pendidikan Matematika Universitas Timor, ${ }^{2,3}$ Universitas Timor \\ *elfridakolo04@gmail.com
}

Diterima: 24 September 2020 Disetujui: 14 Februari 2021 Dipublikasikan: 28 Februari 2021

\begin{abstract}
ABSTRAK
Penelitian ini bertujuan untuk meningkatkan hasil belajar matematika materi aritmetika sosial pada siswa SMP Negeri 3 Atambua menggunakan model pembelajaran Problem Based Learning (PBL). Jenis penelitian ini adalah penelitian tindakan kelas. Subjek dalam penelitian ini adalah siswa kelas VII ${ }^{\text {B1 }}$ SMP Negeri 3 Atambua pada semester genap tahun ajaran 2019/2020 yang berjumlah 15 orang. Instrumen pengumpulan data dalam penelitian ini adalah lembar observasi dan soal tes. Penelitian ini dilaksanakan dalam dua siklus dan masing - masing siklus terdiri dari tiga kali pertemuan, untuk proses belajar mengajar dan tes. Hasil penelitian menunjukkan bahwa dengan menggunakan model pembelajaran ProblemBased Learning (PBL) hasil belajar siswa meningkat. Hal ini dapat dilihat dari hasil belajar siswa pada siklus I persentase ketuntasan kelas mencapai $60 \%$. Sedangkan pada siklus II persentase ketuntasan kelas meningkat menjadi 86,66\%. Dengan demikian peneliti menyimpulkan bahwa dengan menggunakan model pembelajaran PBL dapat meningkatkan hasil belajar matematika materi aritmetika sosial siswa kelas VII ${ }^{\text {B1 }}$ SMP Negeri 3 Atambua.

Kata kunci: Problem Based Learning, Hasil Belajar, Aritmetika Sosial.
\end{abstract}

\section{ABSTRACT}

This study aims to improve the mathematics learning outcomes of social arithmetic material in students of SMP Negeri 3 Atambua using the Problem Based Learning (PBL) learning model. This type of research is classroom action research. The subjects in this study were students of class VII B1 SMP Negeri 3 Atambua in the even semester of the 2019/2020 school year, totaling 15 people. The data collection instruments in this study were the observation sheet and test questions. This research was conducted in two cycles and each cycle consisted of three meetings, for teaching and learning processes and tests. The results showed that by using the PBL learning model, student learning outcomes increased, this can be seen from the student learning outcomes in cycle I the percentage of class completeness reached $60 \%$. While in cycle II the percentage of class completeness increased to $86.66 \%$. Thus, the researchers concluded that using the PBL learning model can improve the results of learning mathematics social arithmetic material for class VII B1 students of SMP Negeri 3 Atambua.

Keywords: Problem Based Learning, Learning Outcomes, Social Arithmetic.

\section{Pendahuluan}

Pendidikan merupakan usaha sadar untuk menyiapkan siswa melalui kegiatan bimbingan, pengajaran, dan latihan. Pendidikan sangat berperan penting dalam perkembangan dan pembangunan masa depan suatu bangsa. Matematika merupakan salah satu mata pelajaran yang diajarkan kepada siswa mulai dari pendidikan dasar hingga perguruan tinggi. Siswa perlu menguasai konsep - konsep dasar matematika agar dapat mengaplikasikannya dalam kehidupan sehari - hari. Hal ini sesuai dengan salah satu tujuan pembelajaran matematika di SMP yaitu agar siswa memiliki kemampuan memahami konsep konsep matematika sehingga siswa dapat menjelaskan keterkaitan antar konsep, mengaplikasikannya secara benar dan tepat. Guru merupakan salah satu faktor yang memegang peranan penting dalam 


\section{Range: Jurnal Pendidikan Matematika Vol. 2 No. 2 Tahun 2021 Elfrida Kolo, dkk}

tercapainya tujuan pembelajaran matematika karena dalam proses pembelajaran matematika guru secara langsung dapat mempengaruhi, membina dan meningkatkan kecerdasan serta keterampilan siswa.

Berdasarkan hasil wawancara dengan guru mata pelajaran matematika di SMP Negeri 3 Atambua terdapat permasalahan saat proses pembelajaran matematika di sekolah, yakni siswa kurang memahami konsep matematika, kurang teliti dalam penggunaan rumus, kurang teliti dalam pemakaian simbol dan siswa kurang teliti dalam perhitungan serta penyelesaian soal salah satu materinya yaitu aritmetika sosial dimana siswa kurang memahami konsep dari aritmetika sosial, siswa kurang teliti dalam pemakaian rumus dalam aritmetika sosial padahal konten materinya banyak yang berkaitan dengan kehidupan sehari - hari. Masalah tersebut timbul karena dalam menyampaikan materi guru langsung menjelaskan konsep, diikuti rumus - rumus, lalu contoh soal dan setelah itu siswa diminta mengerjakan latihan soal berdasarkan contoh yang diberikan sehingga apabila terdapat soal cerita yang redaksi kalimatnya sedikit berubah siswa kurang mampu menyelesaikan soal tersebut. Metode pembelajaran yang dominan digunakan di sekolah tersebut adalah metode ceramah dengan alasan agar materi ajar yang disampaikan selesai sesuai dengan waktu yang terdapat pada perangkat pembelajaran. Akibatnya hasil belajar siswa kurang memuaskan yang ditandai masih banyak siswa yang mendapatkan nilai di bawah KKM (Kriteria Kelulusan Minimum) yang ditentukan oleh pihak sekolah. Kondisi tersebut diduga kuat karena pemilihan dan penggunaaan model pembelajaran oleh guru yang belum tepat.

Penggunaan model pembelajaran yang tepat akan berdampak positif pada hasil belajar peserta didik. Menurut Permendikbud 103 tahun 2014 Model pembelajaran merupakan suatu bentuk pembelajaran yang memiliki nama, ciri, sintaks, pengaturan dan budaya misalnya discovery learning, project - based learning, problem based learning, inquiry learning. Dari beberapa tipe model pembelajaran tersebut peneliti memilih menggunakan model pembelajaran Problem Based Learning untuk meningkatkan hasil belajar matematika materi aritmetika sosial siswa kelas VII ${ }^{\mathrm{B} 1}$ SMP Negeri 3 Atambua. Pemilihan model pembelajaran PBL karena model pembelajaran ini menggunakan masalah dunia nyata sebagai suatu konteks bagi siswa untuk belajar tentang berpikir kritis dan keterampilan pemecahan masalah, serta untuk memperoleh pengetahuan dan konsep yang esensi dari mata pelajaran (Komalasari, Kokom 2011 : 58 - 59). Model pembelajaran PBL adalah suatu model pembelajaran yang berbasis masalah nyata dan materi aritmetika sosial konten materinya berkaitan dengan kehidupan sehari - hari, sehingga model pembelajaran PBL cocok dengan materi aritmetika sosial. Selain itu ada juga hasil penelitian yang menggunakan PBL yaitu penelitian yang dilakukan oleh Bungel (2015) yang menyimpulkan bahwa melalui penerapan model pembelajaran PBL pada mata pelajaran matematika materi prisma dapat meningkatkan hasil belajar.

Dalam penelitian ini peneliti mengangkat masalah mengenai rendahnya hasil belajar siswa materi aritmetika sosial. Untuk mengatasi masalah tersebut peneliti menggunakan model pembelajaran PBL. Karena model pembelajaran Problem Based Learning (PBL) dalam pembelajarannya menggunakan masalah nyata sehingga siswa tertantang untuk menyelesaikan masalah yang diberikan dan dapat meningkatkan hasil belajar matematika siswa materi aritmetika sosial.

PBL pertama kali dikenalkan oleh Don Woods berdasarkan penelitiannya dengan para mahasiswa kimia di universitas Mc. Master di Kanada pada tahun 1960an (Mayasari dkk, 2016). Problem Based Learning merupakan metode instruksional yang menantang peserta didik agar belajar bekerjasama dalam kelompok untuk mencari solusi dari masalah yang nyata (Gunantara dkk, 2014 : 2). Problem Based Learning merupakan model pembelajaran yang diawali dengan masalah untuk mengumpulkan dan mengintegrasikan pengetahuan baru (Fathurrohman, 2015 : 4). Problem Based Learning adalah model pembelajaran yang melibatkan siswa dalam memecahkan masalah nyata (Gunantara dkk, $2015: 2$ ). Dalam pembelajaran menggunakan model pembelajaran Problem Based Learning apabila dijalankan dengan baik dapat meningkatkan hasil belajar peserta didik yang lebih tinggi daripada pembelajaran dengan model pembelajaran konvensional. Menurut Heriawan (dalam Usman \& Ekasatya, 2017 : 72) Penerapan model pembelajaran Problem Based Learning untuk membantu siswa mengembangkan kemampuan berfikir, pemecahan masalah, dan keterampilan intelektual. Hal ini disebabkan metode 


\section{Range: Jurnal Pendidikan Matematika Vol. 2 No. 2 Tahun 2021 Elfrida Kolo, dkk}

pembelajaran Problem Based Learning menghadirkan suasana yang penuh dengan motivasi dan saling ketergantungan secara positif.

Langkah - langkah model pembelajaran Problem Based Learning menurut Sitiatava Rizema Putra (dalam Caesariani, 2018 : 836) adalah sebagai berikut

Fase 1 : Orientasi siswa pada masalah,

guru menjelaskan tujuan pembelajaran, mengajukan masalah dan meminta siswa untuk mencermati masalah tersebut, serta memotivasi siswa untuk terlibat dalam pemecahan masalah yang dipilih.

Fase 2 : Mengorganisasi siswa untuk belajar,

guru membimbing siswa untuk memecahkan suatu permasalahan dengan cara bekerja sama satu dengan yang lain, membagi siswa dslam kelompok yang bervariasi, masing - masing kelompok beranggotakan $4-5$ orang, dan membagikan LKS untuk dikerjakan.

Fase 3 : Membimbing penyelidikan individual maupun kelompok,

guru mendorong siswa untuk mengumpulkan informasi yang sesuai, melaksanakan eksprimen untuk mendapatkan penjelasan dan pemecahan masalah.

Fase 4 : Mengembangkan dan menyajikan hasil karya,

guru meminta salah satu anggota kelompok untuk mempresentasikan hasil diskusi dan membantu jika siswa mengalami kesulitan.

Fase 5 : Menganalisis dan mengevaluasi proses pemecahan masalah,

guru membantu siswa untuk melakukan refleksi atau evaluasi terhadap penyelidikan siswa dan proses - proses yang siswa gunakan dan menarik suatu kesimpulan.

Adapun beberapa kelebihan PBL menurut Hamruni (dalam Caesariani, 2018 : 837) sebagai berikut : 1) Merupakan teknik yang cukup bagus untuk lebih memahami isi pelajaran. 2) Menantang kemampuan siswa serta memberikan kepuasan untuk menemukan pengetahuan baru bagi siswa. 3) Meningkatkan aktivitas pembelajaran siswa. 4) Membantu siswa mentransfer pengetahuan mereka untuk memahami masalah dalam kehidupan nyata. 5) Membantu siswa untuk mengembangkan pengetahuan barunya dan bertanggung jawab dalam pembelajaran yang dilakukan oleh siswa. 6) Mendorong siswa untuk melakukan evaluasi sendiri, baik terhadap hasil maupun proses belajarnya. 7) Memperlihatkan pada siswa bahwa setiap mata pelajaran pada dasarnya merupakan cara berpikir dan sesuatu yang harus dimengerti oleh siswa, bukan hanya sekedar belajar dari guru atau buku - buku saja. 8) Lebih menyenangkan dan disukai siswa. 9) Mengembangkan kemampuan siswa untuk berpikir kritis dan kemampuan mereka untuk menyesuaikan dengan pengetahuan baru. 10) Memberi kesempatan pada siswa untuk mengaplikasikan pengetahuan yang mereka miliki dalam dunia nyata. 11) Mengembangkan minat siswa untuk secara terus - menerus belajar meskipun belajar pada pendidikan formal telah berakhir. Sedangkan kelemahan dari PBL menurut Sitiatava Rizema Putra (dalam Caesariani, 2018 : 837) adalah sebagai berikut : 1) Bagi siswa yang malas, maka tujuan dari pendekatan PBL tidak dapat dicapai. 2) Membutuhkan waktu. 3) Tidak semua mata pelajaran dapat diterapkan model pembelajaran PBL.

Menurut penelitian terdahulu yang dilakukan oleh Gunantara dkk (2014) salah satu model pembelajaran yang dapat dikembangkan dan diadopsi untuk menempatkan siswa sebagai pusat pembelajaran adalah penerapan model pembelajaran problem based learning. Menurut Triyanto Problem based learning adalah salah satu pendekatan pembelajaran dengan membuat konfrontasi kepada siswa dan masalah - masalah praktis atau pembelajaran yang dimulai dengan pemberian masalah dan memiliki konteks dengan dunia nyata. Model pembelajaran problem based learning sangat cocok diterapkan untuk semua mata pelajaran, termasuk mata pelajaran matematika. Setyirini dkk (2011) mengungkapkan melalui Problem Based Learning dengan kelompok yang heterogen memungkinkan siswa untuk saling bertukar pikiran, bekerja sama untuk memecahkan masalah yang pada akhirnya dapat meningkatkan kemampuan berpkir kritis.

Arimetika sosial merupakan bagian dari matematika yang disebut ilmu hitung. Dalam ilmu hitung dibicarakan tentang sifat - sifat bilangan, dasar - dasar pengerjaan seperti menjumlah, mengurang, membagi, mengalikan, menarik akar dan lainnya. Materi artimetika sosial lebih menekankan pada 


\section{Range: Jurnal Pendidikan Matematika Vol. 2 No. 2 Tahun 2021 Elfrida Kolo, dkk}

kemampuan siswa dalam memahami konsep matematika kontekstual yang menggambarkan kehidupan sehari - hari, soal - soal yang diberi kan menuntut siswa untuk mampu memecahkan masalah yang berbentuk soal cerita (Prisiska dkk, 2017 : 83). Model pembelajaran PBL merupakan salah saru model pembelajaran yang sangat cocok untuk materi artimetika sosial karena keduanya membahas masalah nyata dalam kehidupan sehari - hari.

\section{Metode Penelitian}

Berisi jenis penelitian, waktu dan tempat penelitian, target/sasaran, subjek penelitian, prosedur, instrumen dan teknik analisis data serta hal-hal lain yang berkait dengan cara penelitiannya. target/sasaran, subjek penelitian, prosedur, data dan instrumen, dan teknik pengumpulan data serta teknik analisis data. Jenis penelitian ini adalah penelitian tindakan kelas (PTK). PTK merupakan penelitian yang dilakukan oleh guru di kelasnya sendiri melalui refleksi diri dengan tujuan untuk memperbaiki proses belajar mengajar sehingga hasil belajar siswa meningkat (Supardi \& Suharsimi, 2009). Penelitian ini dilaksanakan di SMP Negeri 3 Atambua dengan subjek penelitian adalah siswa kelas VII ${ }^{\mathrm{B} 1}$. Jenis data yang digunakan dalam penelitian ini adalah data primer berupa data hasil pengamatan aktivitas siswa dan guru serta hasil belajar matematika. Instrumen yang digunakan untuk mengumpulkan data dalam penelitian ini adalah lembar observasi dan soal tes. Teknik pengumpulan data dengan Pengamatan dan Tes tertulis. Pengamatan dilakukan selama proses pembelajaran setiap siklus sedangkan tes dilakukan di akhir pertemuan setiap siklus.

Penelitian ini dilaksanakan dalam II siklus yang mana setiap siklus berlangsung selama 1 minggu dengan 2 kali pertemuan. Siklus I terdiri 4 tahapan. Tahap pertama berupa perencanaan yang meliputi: 1) Melakukan konsultasi dengan guru mata pelajaran; 2) Membuat jadwal dengan guru mata pelajaran; 3) Membuat perangkat pembelajaran; 4) Membuat pedoman pengamatan atau observasi; 5) Membuat butir soal tes setiap siklus. Tahap kedua berupa tindakan yang meliputi: 1) Orientasi siswa pada masalah, guru menjelaskan tujuan pembelajaran, mengajukan masalah dan meminta siswa untuk mencermati masalah tersebut, serta memotivasi siswa untuk terlibat dalam pemecahan masalah yang dipilih; 2) Mengorganisasi siswa untuk belajar, guru membimbing siswa untuk memecahkan suatu permasalahan dengan cara bekerja sama satu dengan yang lain, membagi siswa dslam kelompok yang bervariasi, masing - masing kelompok beranggotakan 4 - 5 orang, dan membagikan LKS untuk dikerjakan; 3) Membimbing penyelidikan individual maupun kelompok, guru mendorong siswa untuk mengumpulkan informasi yang sesuai, melaksanakan eksprimen untuk mendapatkan penjelasan dan pemecahan masalah; 4) Mengembangkan dan menyajikan hasil karya, guru meminta salah satu anggota kelompok untuk mempresentasikan hasil diskusi dan membantu jika siswa mengalami kesulitan; 5) Menganalisis dan mengevaluasi hasil pemecahan masalah, guru membantu siswa untuk melakukan refleksi atau evaluasi terhadap penyelidikan mereka dan proses - proses yang mereka gunakan dan menarik suatu kesimpulan. Tahap ketiga berupa observasi yang dilakukan untuk memperoleh gambaran lengkap secara objektif tentang perkembangan proses pembelajaran dan pengaruh dari perlakuan yang diberikan melalui model pembelajaran PBL terhadap perilaku siswa dalam mengikuti kegiatan belajar mengajar. Tahap keempat berupa refleksi, pada akhir setiap siklus peneliti, guru dan mitra peneliti berkolaborasi merefleksikan hasil observasi dan tes untuk mengetahui keberhasilan dan kekurangan dari siklus 1 dan merencanakan perbaikan. Siklus II, setelah diadakan refleksi terhadap pelaksanaan observasi dan tes pada siklus I, maka pelaksanaan tindakan siklus II akan mengacu hasil perencanaan pada siklus I. Siklus ke - n, setelah diadakan refleksi terhadap pelaksanaan observasi dan tes pada siklus sebelumnya, maka pelaksanaan tindakan siklus selanjutnya akan mengacu hasil perencanaan pada siklus sebelumnya.

Teknik analisis data dalam penelitian ini meliputi:

1) Analisa Data hasil pengamatan terhadap aktivitas siswa dan hasil pengamatan terhadap aktivitas guru yang dilakukan pada setiap siklus dengan rumus sebagai berikut :

$$
P=\frac{\text { jumlah skor yang diperoleh }}{\text { banyaknya aspek yang diamati }} \text {. }
$$




\section{Range: Jurnal Pendidikan Matematika Vol. 2 No. 2 Tahun 2021 Elfrida Kolo, dkk}

Dengan kategori sebagai berikut:

$2,00 \leq p<2,5 \quad=$ kurang baik

$2,50 \leq p<3,00 \quad=$ cukup baik

$3,00 \leq p<3,50 \quad=$ baik

$3,50 \leq p<4,00 \quad=$ sangat baik

Keterangan $\mathrm{P}=$ rata - rata. (Sudjana, $2011: 78$ )

2) Analisis data hasil tes yang dikumpulkan pada setiap siklus dianalisa untuk mengetahui tingkat ketuntasan siswa. Dalam penelitian ini untuk mengetahui ketuntasan individu maupun klasikal digunakan pedoman ketuntasan belajar sebagai berikut:

a. Ketuntasan Individu, Seorang siswa dikatakan telah berhasil (mencapai ketuntasan belajar) bila telah mencapai target penugasan minimal 75\% atau dengan nilai diatas 75 (ketetapan dari sekolah). Rumus yang digunakan adalah :

Persentase siswa yang diharapkan $=\frac{T}{T t} \times 100 \%$

Keterangan :

$\mathrm{T}=$ jumlah skor yang diperoleh

$\mathrm{Tt}=$ jumlah skor total (Trianto, $2009: 14$ ).

b. Ketuntasan kelompok, Suatu kelas dikatakan telah berhasil (mencapai ketuntasan belajar) jika paling sedikit $75 \%$ data jumlah sisa dalam kelas telah mencapai ketuntasan perorangan. Rumus yang digunakan:

Persentase ketuntasan kelas $=\frac{\sum x}{M} \times 100 \%$

Keterangan:

$\sum x=$ jumlah siswa yang tuntas

$M=$ jumlah siswa dalam kelas (Sukiman, 2013: 225).

Indikator keberhasilan, jika dalam suatu kelas, ketuntasan siswa lebih atau sama dengan $75 \%$ maka pembelajaran yang dilaksanakan berhasil tetapi jika ketuntasan belajar kurang dari 75\%, maka pembelajaran yang dilaksanakan belum berhasil dan dilanjutkan dengan siklus berikutnya.

\section{Hasil Penelitian dan Pembahasan}

Penelitian yang dilakukan oleh Bungel (2015) yang menyimpulkan bahwa melalui penerapan model pembelajaran PBL pada mata pelajaran matematika materi prisma dapat meningkatkan hasil belajar. Hasil penelitian siklus I dan II dapat dilihat pada Tabel berikut.

Tabel 1. Data Hasil Tes Siklus I dan II

\begin{tabular}{lccccccc}
\hline \multirow{2}{*}{ No } & \multirow{2}{*}{ Nama } & \multirow{2}{*}{ Siswa } & Siklus I & Siklus II & No & Nama Siswa & Siklus I Siklus II \\
\hline 1 & APK & 72 & 75 & 9 & AS & 76 & 79 \\
2 & SBK & 70 & 76 & 10 & DMS & 67 & 79 \\
3 & AFK & 77 & 80 & 11 & DGM & 60 & 70 \\
4 & AGDR & 0 & 72 & 12 & FCM & 75 & 75 \\
5 & AH & 76 & 80 & 13 & FKM & 77 & 80 \\
6 & ABM & 90 & 100 & 14 & GN & 68 & 78 \\
7 & AJ & 80 & 80 & 15 & GIL & 80 & 80 \\
8 & RCP & 75 & 80 & & & & \\
\hline
\end{tabular}

Berdasarkan Tabel 1 hasil penelitian yang diperoleh pada tindakan siklus I mencapai persentase ketuntasan kelas sebesar 60\%. Capaian ini belum sesuai indikator ketuntasan yang diharapkan yaitu $75 \%$ 


\section{Range: Jurnal Pendidikan Matematika Vol. 2 No. 2 Tahun 2021 Elfrida Kolo, dkk}

karena masih banyak siswa yang belum memahami dan belum mampu menyelesaikan soal aritmetika sosial yang berkaitan dengan persentase untung dan persentase rugi, harga beli apabila harga jual dan persentase kerugian diketahui.

Aktivitas siswa dalam mengikuti proses pembelajaran pada siklus I pada pertemuan pertama memperoleh nilai rata - rata 2,25 dan pertemuan kedua memperoleh nilai rata - rata 2,50. Sehingga aktivitas siswa pada siklus I memperoleh rata - rata nilai 2,375 dengan kategori cukup baik. Hal ini disebabkan oleh beberapa hal yakni: 1) Suasana kelas kurang tertib karena saat menyampaikan pendapat siswa tidak saling mendengarkan, 2) Kerja sama dalam kelompok diskusi masih kurang, 3) Belum mampu menyelesaikan masalah dalam LKS, 4) Siswa belum berani dalam memberikan tanggapan terhadap hasil diskusi kelompok lain, 5) Siswa malu bertanya apa yang belum dipahami, 6) Belum mampu menyimpulkan masalah yang diberikan. Aktivitas guru dalam mengikuti proses pembelajaran pada siklus I pada pertemuan pertama memperoleh nilai rata - rata 3,00 dan peretemuan kedua memperoleh nilai rata - rata 3,16. Sehingga aktivitas guru pada siklus I memperoleh rata - rata nilai 3,08 dengan kategori baik.

Setelah peneliti berdiskusi dengan mitra peneliti diperoleh beberapa masukan dan perbaikan untuk dijadikan pedoman dalam pelaksanaan tindakan pada siklus II. Masukan dan perbaikan tersebut antara lain ; 1) Peneliti harus memberi perhatian khusus kepada siswa yang kurang tertib dalam berdiskusi dengan cara melontarkan beberapa pertanyaan untuk dijawab, 2) Peneliti harus terus memotivasi siswa agar terlibat aktif dalam diskusi kelompok, 3) Peneliti harus terus memotivasi siswa agar berani menyampaikan pendapat, 4) Memberikan bimbingan kepada siswa yang kurang mampu dalam memahami materi yang diajarkan maupun dalam dalam menyelesaikan LKS, 5) Terus memotivasi siswa agar terlibat aktif dalam diskusi kelompok.

Berdasakan hasil refleksi mitra peneliti kepada peneliti, peneliti berusaha memperbaiki kekurangan yang ada pada siklus II . Atas saran dan perbaikan pada siklus I, persentase ketuntasan kelas pada siklus II sebesar $86.66 \%$. Persentase ketuntasan kelas meningkat sebesar 26,66\%. Perolehan ketuntasan ini disebabkan karena peneliti benar - benar mengikuti saran dari mitra peneliti saat refleksi pada siklus I. Capaian ini telah melebihi indikator keberhasilan yang diharapkan. Terjadi peningkatan persentase ketuntasan kelas pada siklus II ini terjadi karena hasil pengamatan pelaksanaan tindakan siklus II terlihat bahwa siswa sudah mengikuti proses pembelajaran dengan sangat baik yaitu suasana kelas sudah tertib karena saat menyampaikan pendapat siswa mendengarkan, kerja sama dalam kelompok diskusi semakin baik, siswa sudah mampu menyelesaikan masalah dalam LKS, Siswa sudah berani dalam memberikan tanggapan terhadap hasil diskusi kelompok lain, siswa sudah berani bertanya apa yang belum dipahami, siswa sudah mampu menyimpulkan masalah yang diberikan. Siswa yang tidak tuntas pada siklus I menjadi tuntas pada siklus II yaitu siswa APK, SBK, DMS, dan GN. Hal ini menunjukkan bahwa mengalami peningkatan pada siklus II.

Aktivitas siswa dalam mengikuti proses pembelajaran pada siklus II pada pertemuan pertama memperoleh nilai rata - rata 3,00 dan pertemuan kedua memperoleh nilai rata - rata 3,50. Sehingga aktivitas siswa pada siklus II memperoleh rata - rata nilai 3,25 dengan kategori baik. Aktivitas guru dalam mengikuti proses pembelajaran pada siklus II pada pertemuan pertama memperoleh nilai rata - rata 3,33 dan pertemuan kedua memperoleh nilai rata - rata 3,83. Sehingga aktivitas siswa pada siklus II memperoleh rata - rata nilai 3,58 dengan kategori sangat baik.

Data hasil siklus I dan II menggambarkan bahwa pelaksanaan pembelajaran menggunakan model pembelajaran PBL dapat menigkatkan hasil belajar siswa. Hal ini terbukti dari siklus I jumlah siswa yang tuntas 9 orang meningkat pada siklus II menjadi 13 orang. Dengan persentase ketuntasan kelas pada siklus I sebesar 60\% meningkat sebesar 26,66\% menjadi 86,66\% Pada siklus II. Peningkatan hasil belajar disebabkan karena pembelajaran matematika dengan menggunakan model pembelajaran PBL dapat menunjang proses belajar siswa yang berkaitan dengan kemampuan berpikir, memecahkan masalah dan kemampuan intelektual sehingga mendewasakan siswa menjadi pelajar yang mandiri. Ada juga hasil penelitian yang menggunakan PBL yaitu penelitian yang dilakukan oleh Bungel (2015) yang 


\section{Range: Jurnal Pendidikan Matematika Vol. 2 No. 2 Tahun 2021 Elfrida Kolo, dkk}

menyimpulkan bahwa melalui penerapan model pembelajaran PBL pada mata pelajaran matematika materi prisma dapat meningkatkan hasil belajar.

Model pembelajaran berbasis masalah juga merupakan suatu model pembelajaran yang melibatkan peserta didik untuk belajar kreatif dan mampu memecahkan masalah sehingga memperoleh suatu pengetahuan yang berhubungan dengan masalah tersebut. Pada model pembelajaran ini setiap peserta didik mampu untuk mencari dan menentukan sumber - sumber pengetahuan yang relevan. Pembelajaran bebasis masalah memberi tantangan kepada peserta didik untuk belajar mandiri. Dalam hal ini peserta didik diajak untuk membentuk suatu pengetahuan dengan sedikit bimbingan dan arahan guru. Dengan demikian dapat disimpulkan bahwa penggunaan model pembelajaran PBL di kelas dapat meningkatkan hasil belajar matematika materi aritmetika sosial pada siswa kelas VII ${ }^{\mathrm{B} 1}$ SMP Negeri 3 Atambua.

\section{Kesimpulan}

Simpulan dapat bersifat generalisasi temuan sesuai permasalahan penelitian, dapat pula berupa rekomendatif untuk langkah selanjutnya. Berdasarkan hasil penelitian dan pembahasan maka peneliti dapat menyimpulkan bahwa dengan menggunakan model pembelajaran PBL dapat meningkatkan hasil belajar matematika materi aritmetika sosial pada siswa kelas VII ${ }^{\mathrm{B}}$ SMP Negeri 3 Atambua. Hal ini dapat dilihat dari persentase ketuntasan kelas pada setiap siklus. Pada siklus I persentase ketuntasan kelas $60 \%$, dan pada siklus II mengalami ketuntasan dengan persentase ketuntasan kelas 86,66\%. Aktivitas siswa dalam mengikuti proses pembelajaran pada siklus II baik, siswa terlihat aktif yang ditunjukan pada data hasil aktivitas siswa memperoleh nilai rata - rata 3,25 dengan kategori baik. Aktivitas guru dalam mengikuti proses pembelajaran pada siklus II juga sangat baik, yang ditunjukan pada data hasil aktivitas guru memperoleh nilai rata - rata 3,58 dengan kategori sangat baik. Proses pembelajaran pada siklus II, aktivitas guru mengalami peningkatan, dimana aspek deskriptor pada siklus I tidak terlaksana tetapi pada siklus II diperhatikan dan terlaksana pada siklus II sehingga proses pembelajaran semakin baik.

\section{Saran}

Dari kesimpulan di atas dapat disarankan bagi guru agar dapat menggunakan model pembelajaran PBL dalam proses pembelajaran matematika sehingga materi yang dianggap sulit menjadi mudah dipahami agar hasil belajar siswa dapat meningkat dan bagi sekolah agar dapat memanfaatkan model pembelajaran PBL sebagai bahan pertimbangan untuk meningkatkan kualitas pembelajaran matematika.

\section{Daftar Pustaka}

Bungel, F. M. (2014). Penerapan Model Pembelajaran Problem Based Learning Untuk Meningkatkan Hasil Belajar Siswa Kelas VIII SMP Negeri 4 Palu pada Materi Prisma. Jurnal Elektronik Pendidikan Matematika Tadulako, 2 (1), (pp. 45 - 54).

Caesariani, A. N. (2018). Pemanfaatan Multimedia Interaktif Pada Model Problem Based Learning (PBL) dalam Pembelajaran Matematika. Jurnal Pendidikan Tambusai, 2 ( 4 ) hal 832 - 840.

Faturrohman. (2015). Model - Model Pembelajaran. Jogjakarta : Ar - Ruzz media.

Gunantara, Gd ., dkk 2014. Penerapan Model Pembelajaran Problem Based Learning Untuk Meningkatkan Kemampuan Pemecahan Masalah Matematika Siswa Kelas V. Jurnal Mimbar PGSD, 2 (1), (pp. 1 - 10).

Kemendikbud. (2013). Matematika SMP / MTs kelas VII. Jakarta: Kementrian Pendidikan dan Kebudayaan.

Komalasari, K. (2011). Pembelajaran Kontekstual.Bandung : PT. Refika Aditama.

Mayasari., dkk. (2016). Apakah Model Pembelajaran Problem Based Learning dan Project Based Learning Mampu Melatihkan Keteremapilan Abd 21?.Jurnal Pendidikan Fisika dan Keimuan, 2 (1), (pp. $48-55)$. 


\section{Range: Jurnal Pendidikan Matematika Vol. 2 No. 2 Tahun 2021 Elfrida Kolo, dkk}

Prisiska, N.R., dkk. (2017). Pengembangan LKS Berbasis Problem based Learning materi Aritmetika sosial kelas VII. Jurnal Penelitian dan Pembelajaran Matematika, 10 ( 2 ), (pp. 82 - 94).

Setyorini, U., dkk. (2011). Penerapan Model Problem Based Learning untuk Meningkatkan Kemampuan Berpikir kritis siswa SMP. Jurnal pendidikan Fisika Indonesia, 7 (1), (pp. 52 - 56).

Sudjana, N. (2011). Penilaian Hasil Belajar Mengajar. Bandung: Remaja Rosdakarya.

Sukiman. (2013). Pengembagan Sistem Evaluasi. Yogyakarta: Insan Madani.

Supardi \& Suharsimi. (2009). Penelitian tindakan kelas. Jakarta: Bumi aksara.

Trianto. (2009). Mendesain Model Pembelajaran Inovatif Progresif (Konsep, landasan dan Implementasinya ) pada Kurikulum Tingkat Satuan pendidikan. Jakarta: Kencana Prenada Media. 